\title{
A randomized trial of aripiprazole vs blonanserin for the treatment of acute schizophrenia and related disorders
}

This article was published in the following Dove Press journal:

Neuropsychiatric Disease and Treatment

28 November 2016

Number of times this article has been viewed

\author{
Taro Kishi' \\ Yuki Matsuda' \\ Shinji Matsunaga' \\ Tomohiko Mukai ${ }^{1,2}$ \\ Masatsugu Moriwaki ${ }^{1,2}$ \\ Hideaki Tabuse ${ }^{3}$ \\ Kiyoshi Fujita ${ }^{2}$ \\ Nakao Iwata' \\ 'Department of Psychiatry, Fujita \\ Health University School of Medicine, \\ Toyoake, Aichi, ${ }^{2}$ Department of \\ Psychiatry, Okehazama Hospital, \\ Toyoake, Aichi, ${ }^{3}$ Department of \\ Psychiatry, Holy Cross Hospital, \\ Toki, Gifu, Japan
}

Correspondence: Taro Kishi Department of Psychiatry, Fujita Health University School of Medicine, I-98 Dengakugakubo, Kutsukake-cho,

Toyoake, Aichi 470-I 192, Japan

$\mathrm{Tel}+8 \mid 562939250$

Fax +8I $56293|83|$

Email tarok@fujita-hu.ac.jp
Objective: There has been no direct comparison of aripiprazole and blonanserin for schizophrenia treatment. We conducted a 24 -week, rater-masked, randomized trial of aripiprazole (6-30 mg/d) vs blonanserin (4-24 mg/d) in schizophrenia patients who were not taking any antipsychotic medication for more than 2 weeks before enrollment (UMIN000011194).

Methods: The primary outcome measure for efficacy was improvement of Positive and Negative Syndrome Scale (PANSS) total score at week 24. Secondary outcomes were PANSS subscale scores, 21-item Hamilton Rating Scale for Depression (HAMD-21) score, response rate, discontinuation rate, and individual adverse events.

Results: Forty-four patients were recruited. The discontinuation rate was $86.4 \%$ in the aripiprazole group and $68.2 \%$ in the blonanserin treatment group. There was no significant difference in mean time to discontinuation between the groups. Although both treatment groups showed significant reductions in the PANSS total score, PANSS subscale scores, and HAMD-21 scores at week 24, the magnitudes of the changes did not differ between the groups. There were no significant differences in the incidences of adverse events including somnolence, extrapyramidal symptoms, prolactin-related adverse events, and weight change between the groups.

Conclusion: Our results suggest similar efficacy and safety profiles of aripiprazole and blonanserin in the patients with schizophrenia. Double-blind controlled studies are needed to further explore the efficacy and safety of aripiprazole and blonanserin in schizophrenia.

Keywords: aripiprazole, blonanserin, schizophrenia, efficacy, safety, randomized trial

\section{Introduction}

Several schizophrenia treatment guidelines recommend that antipsychotics with lower risk of adverse events be selected for the treatment of schizophrenia. ${ }^{1-3}$ For example, weight gain is one of the metabolic adverse events in patients treated with antipsychotics. This has serious implications on patient's health and quality of life. ${ }^{4}$ Obesity causes diabetes and hyperlipidemia. Moreover, these chronic health conditions can lead to arteriosclerotic cardiovascular disease. ${ }^{4}$ Aripiprazole, lurasidone, and ziprasidone are known to be low-risk antipsychotics when metabolic adverse events are taken into consideration, whereas clozapine, olanzapine, and zotepine are considered high-risk. ${ }^{4-6}$ These antipsychotics are classified as a second-generation antipsychotic (SGA).

Our meta-analysis ${ }^{7}$ revealed that blonanserin (one of the SGAs) is superior to haloperidol in the improvement of the negative symptoms. ${ }^{8}$ In addition, blonanserin carries a lower risk of hyperprolactinemia and weight gain than risperidone. ${ }^{7,9}$ One recent randomized trial reported that there were no significant differences for change in 
Positive and Negative Syndrome Scale (PANSS) total scores and PANSS 5-factor model (negative symptoms, excitation, cognitive disorders, positive symptoms, anxiety/depression) scores between the blonanserin and risperidone treatment groups. ${ }^{10}$ On the other hand, an 8-week, nonrandomized, open-label study reported that blonanserin was superior to risperidone for improvement of depressive symptoms and quality of daily living. ${ }^{11}$ Moreover, blonanserin improved impairments in verbal fluency and executive function as well as work skills. ${ }^{11}$ Another 1-year, open-label study reported that blonanserin improved psychotic symptoms as well as depressive symptoms, and the reduced depressive symptoms were associated with enhanced subjective well-being, subjective quality of life, and verbal memory. ${ }^{12}$ Moreover, no significant changes were shown in any safety measures, such as extrapyramidal and cardiometabolic symptoms, during the study. ${ }^{12}$ These results suggest that, like aripiprazole, blonanserin can be used as a first-line antipsychotic for the treatment of schizophrenia. Aripiprazole and blonanserin are similar in their receptor profiles, ie, these antipsychotics have high affinity to the serotonin $2 \mathrm{~A}$ receptor, dopamine $\mathrm{D}_{2}$ receptor, and dopamine $\mathrm{D}_{3}$ receptor as well as weak affinity to the dopamine $\mathrm{D}_{1}$ receptor, histamine $\mathrm{H}_{1}$ receptor, muscarinic $M_{1}$ receptor, and adrenergic $\alpha_{1}$ receptor. ${ }^{10,13}$ However, there has been no direct comparison between aripiprazole and blonanserin in patients with schizophrenia. Therefore, we conducted a 24-week, rater-masked, randomized trial of aripiprazole vs blonanserin in patients with acute schizophrenia and related disorders.

\section{Methods \\ Subjects}

The present study was conducted from July 2012 to December 2015 at Fujita Health University Hospital, Holy Cross Hospital, and Okehazama Hospital. This trial was registered at the University hospital Medical Information Network Clinical Trials Registry (UMIN000011194). The patients were diagnosed according to the Diagnostic and Statistical Manual of Mental Disorders (Fourth Edition, Text Revision) criteria with consensus of at least two experienced psychiatrists on the basis of unstructured interviews and a review of all medical records. All subjects met the following inclusion criteria: 1) had acute schizophrenia but had not taken any antipsychotic medication for more than 2 weeks before enrollment, 2) were aged between 20-70 years, 3) had no neurologic or systemic diseases, including disturbance of hematopoiesis, 4) had no history of electroconvulsive therapy within 6 months prior to study enrollment, 5) were not pregnant, and 6) had no dependence on any addictive substances other than nicotine in the past 5 years before enrollment. All subjects underwent laboratory blood testing and electrocardiography at the time of enrollment, and no patient was excluded from the study due to a medical condition.

The clinical trial was described in detail, and written informed consent was obtained from all participants and their guardians. This study was approved by the three Ethics Committees of Fujita Health University, Holy Cross Hospital, and Okehazama Hospital.

\section{Procedures}

All patients were randomly assigned to one of the two treatment groups by the central registration office. When the patients satisfied the inclusion and exclusion criteria for this multicenter trial, the randomization procedure (using a random number table) was carried out by the authors, in contact with a central registration office, by telephone. The doses of aripiprazole and blonanserin were slowly increased (initial dose, aripiprazole: $6 \mathrm{mg} / \mathrm{d}$, blonanserin: $4 \mathrm{mg} / \mathrm{d}$ ) as a rule unless severe side effects occurred (in such cases, it was slowly decreased). The maximum doses of aripiprazole and blonanserin were $30 \mathrm{mg} / \mathrm{d}$ and $24 \mathrm{mg} / \mathrm{d}$, respectively. The subsequent antipsychotic dosage was increased or decreased according to the patient's tolerance and therapeutic response. Lorazepam as an anxiolytic, brotizolam and eszopiclone as hypnotics, and biperiden as an anticholinergic drug were allowed during our clinical trial (by prescription and for valid clinical reasons).

\section{Evaluation of psychopathology, tolerability, and safety}

The PANSS and 21-item Hamilton Rating Scale for Depression (HAMD-21) ${ }^{14}$ were completed at baseline and at 4, 8 (PANSS only), 12, and 24 weeks after starting administration or at all of these times until discontinuation as well as at discontinuation. Treatment-emergent adverse events were recorded at each time point, including immediately before the study, upon spontaneous complaint, and through clinical observation using the Udvalg for Kliniske Undersogelser Side Effect Rating Scale. ${ }^{15}$ The Drug-induced Extrapyramidal Symptoms Scale (DIEPSS) ${ }^{16,17}$ was used for evaluation of extrapyramidal symptoms.

The raters who administered the psychometric tests were masked to treatment group allocation, but patients and physicians knew the type of treatment received. Raters were psychologists not involved in any treatment decisions or evaluation of side effects. Therefore, they did not need to 
Table I Baseline characteristics of the patients

\begin{tabular}{|c|c|c|c|c|}
\hline \multirow{2}{*}{$\begin{array}{l}\text { Variable } \\
\text { Male (\%) }\end{array}$} & \multirow{2}{*}{$\begin{array}{l}\text { Aripiprazole } \\
7(31.8)\end{array}$} & \multirow{2}{*}{$\begin{array}{l}\text { Blonanserin } \\
\text { I I (50.0) }\end{array}$} & \multicolumn{2}{|c|}{$\begin{array}{l}\text { Group difference (Student's } \\
t \text {-test or } \chi^{2} \text { test and } P \text {-value) }\end{array}$} \\
\hline & & & $\chi^{2}=1.5 \mid$ & $P=0.219$ \\
\hline Age, years & $42.4 \pm 12.6$ & $36.5 \pm 9.72$ & $t=-1.75$ & $P=0.087 \mid$ \\
\hline First episode (\%) & $13(59.1)$ & $14(63.6)$ & $\chi^{2}=0.096$ & $P=0.757$ \\
\hline Educational history, years & $12.4 \pm 2.70$ & $13.8 \pm 2.02$ & $t=1.96$ & $P=0.0566$ \\
\hline Hospitalization (\%) & $14(63.6)$ & $16(72.7)$ & $\chi^{2}=0.420$ & $P=0.517$ \\
\hline Study center (Okehazama Hospital, \%) & $14(63.6)$ & $14(63.6)$ & $\chi^{2}=0.00$ & $P=1.00$ \\
\hline Married (\%) & $10(45.5)$ & $9(40.9)$ & $\chi^{2}=0.093$ & $P=0.76 \mathrm{I}$ \\
\hline Unemployed (\%) & $17(77.3)$ & $13(59.1)$ & $\chi^{2}=1.69$ & $P=0.193$ \\
\hline Current smoker (\%) & $4(18.2)$ & $7(31.8)$ & $\chi^{2}=1.10$ & $P=0.294$ \\
\hline PANSS total score & $102.1 \pm 15.6$ & $112.5 \pm 29.1$ & $t=1.47$ & $P=0.149$ \\
\hline HAMD-2I total scores & $22.7 \pm 8.96$ & $26.3 \pm 5.62$ & $t=1.53$ & $P=0.133$ \\
\hline Body weight (kg) & $54.4 \pm 12.6$ & $62.0 \pm 13.6$ & $t=1.94$ & $P=0.0587$ \\
\hline DIEPSS total scores & $0.409 \pm 0.210$ & $0.182 \pm 0.210$ & $t=-0.767$ & $P=0.448$ \\
\hline
\end{tabular}

Abbreviations: PANSS, Positive and Negative Syndrome Scale; HAMD-2I, 21-item Hamilton Rating Scale for Depression; DIEPSS, Drug-induced Extrapyramidal Symptoms Scale.

know the pharmacologic treatment. The following measures were taken to maintain the masking of raters: 1) electronic data from the trial were password protected, 2) all case report forms were securely stored, and 3) discussions about patients across research teams were restricted. Moreover, participants were reminded to avoid open discussion of treatment assignment with the raters.

The primary outcome measure was the improvement of PANSS total scores at week 24. The secondary outcomes were the PANSS subscale and HAMD-21 scores, response rate (clinical response defined as $\geq 20 \%$ reduction in the PANSS total score from baseline to end point), discontinuation rate, individual adverse events, and DIEPSS total score.

\section{Statistical analysis}

Modified intent-to-treat analysis was conducted using the last observation carried forward method. Baseline continuous and categorical variables were compared between the treatment groups using independent $t$-test and the $\chi^{2}$ test, respectively. Paired student's $t$-tests were used to evaluate the changes in the psychopathology scores from baseline to end point. The primary comparison between the aripiprazole and blonanserin treatment groups was the change in PANSS score from baseline based on an analysis of covariance (ANCOVA) model, with the baseline PANSS score, educational history, and age as covariates (because we found marginal differences in age $[P=0.0871]$ and educational history $[P=0.0566]$ at baseline between aripiprazole and blonanserin treatment groups [Table 1]). We also used multiple logistic regression analyses to examine which antipsychotic was associated with a higher response rate (dependent variable: response rate; independent variable: treatment group; covariates: baseline PANSS score, educational history, and age). To determine which antipsychotic was more effective for depressive symptoms, we used ANCOVA to analyze the relationship between the antipsychotic and the baseline to end point change in the HAMD-21 total score, with the baseline HAMD-21 score, educational history, and age as covariates. Kaplan-Meier analysis was used to estimate the time to discontinuation for the aripiprazole and blonanserin groups, and results were compared using the log-rank test. We also compared the change in body weight and DIEPSS total score from baseline to end point between aripiprazole and blonanserin treatment groups based on an ANCOVA model with each baseline value as a covariate. Incidences of individual adverse events during the study were compared between aripiprazole and blonanserin treatment groups using the $\chi^{2}$ test.

Statistical analyses were performed using SPSS Statistics for Windows (IBM, Tokyo, Japan) and JMP (JMP 12.2. 1J; SAS Japan Inc., Tokyo, Japan). A $P$-value of $<0.05$ was considered statistically significant for all tests.

\section{Results}

The demographics and other characteristics of the patients are presented in Table 1. Forty-four patients were recruited, all of whom were diagnosed as schizophrenic at enrollment, and $61.4 \%$ were first-episode patients. There were no significant differences in most variables, such as sex ratio, study center distribution, and percentage of first-episode patients, between the treatment groups; however, there were marginal differences in age ( $P=0.0871)$, educational history $(P=0.0566)$, and 
Table 2 End point change in PANSS scores at 4, 8, 12, and 24 weeks from the baseline

\begin{tabular}{|c|c|c|c|c|c|c|c|c|c|c|}
\hline & $\begin{array}{l}\text { Baseline } \\
\text { score }\end{array}$ & $\begin{array}{l}F_{d f} \\
P \text {-value }\end{array}$ & $\begin{array}{l}\text { Change } \\
\text { score at } \\
4 \text { weeks }\end{array}$ & $\begin{array}{l}F_{\text {df }} \\
P \text {-value }\end{array}$ & $\begin{array}{l}\text { Change } \\
\text { score at } \\
8 \text { weeks }\end{array}$ & $\begin{array}{l}F_{\text {df }} \\
P \text {-value }\end{array}$ & $\begin{array}{l}\text { Change } \\
\text { score at } \\
\text { I } 2 \text { weeks }\end{array}$ & $\begin{array}{l}F_{d f} \\
P \text {-value }\end{array}$ & $\begin{array}{l}\text { Change } \\
\text { score at } \\
24 \text { weeks }\end{array}$ & $\begin{array}{l}\boldsymbol{F}_{\text {df }} \\
P \text {-value }\end{array}$ \\
\hline \multicolumn{11}{|c|}{ PANSS total score } \\
\hline Aripiprazole & $102.1 \pm 15.6$ & $F_{1,42}=2.16$ & $-19.3 \pm 17.6$ & $F_{1,39}=0.001$ & $-22.2 \pm 17.6$ & $F_{1,39}=0.012$ & $-21.9 \pm 17.6$ & $F_{1,39}=0.032$ & $-23.4 \pm 18.2$ & $F_{1,39}=0.027$ \\
\hline Blonanserin & $\mid 12.5 \pm 29.1$ & $P=0.149$ & $-24.4 \pm 26.4$ & $P=0.974$ & $-26.6 \pm 25.6$ & $P=0.912$ & $-29.2 \pm 26.3$ & $P=0.858$ & $-30.7 \pm 27.4$ & $P=0.869$ \\
\hline \multicolumn{11}{|c|}{ PANSS positive subscale score } \\
\hline Aripiprazole & $25.4 \pm 5.07$ & $F_{1,42}=0.774$ & $-6.2 \mathrm{I} \pm 5.87$ & $F_{1,39}=0.119$ & $-7.05 \pm 5.82$ & $F_{1,39}=0.147$ & $-7.00 \pm 5.65$ & $F_{1,39}=0.027$ & $-7.42 \pm 6.01$ & $F_{1,39}=0.019$ \\
\hline Blonanserin & $27.1 \pm 7.69$ & $P=0.384$ & $-6.05 \pm 7.11$ & $P=0.732$ & $-6.91 \pm 7.22$ & $P=0.704$ & $-7.55 \pm 7.78$ & $P=0.87 \mid$ & $-8.00 \pm 7.83$ & $P=0.890$ \\
\hline \multicolumn{11}{|c|}{ PANSS negative subscale score } \\
\hline Aripiprazole & $24.4 \pm 6.99$ & $F_{1,42}=1.66$ & $-3.95 \pm 4.90$ & $F_{1,39}=0.020$ & $-4.32 \pm 4.94$ & $F_{1,39}=0.052$ & $-4.16 \pm 5.34$ & $F_{1,39}=0.417$ & $-4.63 \pm 5.07$ & $F_{1,39}=0.277$ \\
\hline Blonanserin & $27.5 \pm 8.59$ & $P=0.204$ & $-6.14 \pm 7.22$ & $P=0.890$ & $-6.09 \pm 7.55$ & $P=0.821$ & $-7.32 \pm 7.07$ & $P=0.522$ & $-7.73 \pm 7.32$ & $P=0.602$ \\
\hline \multicolumn{11}{|c|}{ PANSS general subscale score } \\
\hline Aripiprazole & $52.3 \pm 8.65$ & $F_{1,42}=2.25$ & $-9.16 \pm 9.00$ & $F_{1,39}=0.042$ & $-10.8 \pm 9.22$ & $F_{1,39}=0.007$ & $-10.8 \pm 9.22$ & $F_{1,39}=0.011$ & $-11.4 \pm 9.54$ & $F_{1,39}=0.014$ \\
\hline Blonanserin & $57.9 \pm 15.2$ & $P=0.14 I$ & $-12.2 \pm 14.3$ & $P=0.838$ & $-13.6 \pm \mid 4.1$ & $P=0.934$ & $-14.3 \pm 14.4$ & $P=0.915$ & $-15.0 \pm 15.1$ & $P=0.905$ \\
\hline
\end{tabular}

Note: Covariate: educational history, age, PANSS scores at baseline.

Abbreviations: PANSS, Positive and Negative Syndrome Scale; $d f$, degrees of freedom.

body weight $(P=0.0587)$ at baseline between the treatment groups (Table 1).

The discontinuation rate during the study was $86.4 \%$ in the aripiprazole group and $68.2 \%$ in the blonanserin treatment group (Table S1). The main reasons for discontinuation were lack of efficacy ( $n=3$ for aripiprazole and $n=7$ for blonanserin), adverse events ( $n=5$ for aripiprazole and $n=4$ for blonanserin), and other reasons such as moving and withdrawal of informed consent ( $\mathrm{n}=11$ for aripiprazole and $\mathrm{n}=6$ for blonanserin) (Table S1). There was no significant difference in mean time to discontinuation between the aripiprazole and blonanserin treatment groups $(9.21 \pm 8.75$ weeks vs $11.4 \pm 9.56$ weeks; $\chi^{2}(1)=0.763, P=0.382$; Figure S1). The modified intent-to-treat sample for psychopathology and response rate analyses consisted of 41 patients with baseline assessment and at least one follow-up assessment ( aripiprazole $=19$ patients, blonanserin $=22$ patients), while all 44 patients were entered into the safety analyses. The mean aripiprazole and blonanserin doses at the end point were $11.5 \pm 9.01 \mathrm{mg} / \mathrm{d}$ and $10.3 \pm 6.51 \mathrm{mg} / \mathrm{d}$, respectively.

Both aripiprazole and blonanserin treatments were associated with significant improvements in the PANSS total score and positive, negative, and general subscale scores at weeks 4 , 8, 12, and 24 (Tables S2 and S3). However, there were no significant differences in the magnitudes of the PANSS total and subscale score decreases at any time between the aripiprazole and blonanserin treatment groups (Table 2). There were also no significant differences in response rate at any time point between the treatment groups (Table 3).

Both aripiprazole and blonanserin significantly improved the HAMD-21 scores at all of the time points (Table S4).
There were also marginal differences in the magnitude of the HAMD-21 score decrease at 24 weeks between the aripiprazole and blonanserin treatment groups $\left(F_{1,39}=3.94\right.$, $P=0.055$; Table 4).

There were no significant differences in the incidence of individual adverse events between the groups (Table 5). There were no significant differences in body weight and DIEPSS total score at the end point between the treatment groups (Table 5). No patients had prolactin-related adverse events, corrected QT interval prolongation (on an electrocardiogram), or blood test abnormalities.

\section{Discussion}

The present study is the first randomized trial of aripiprazole vs blonanserin in Japanese patients with schizophrenia and related disorders. There were no significant differences in the efficacy and safety outcomes between the aripiprazole and blonanserin treatment groups. Previous meta-analyses have shown more beneficial effects of aripiprazole for the treatment of depressive symptoms in patients with schizophrenia than those of first-generation antipsychotics ${ }^{18}$ and olanzapine. ${ }^{19}$ Although one recent randomized trial reported

Table 3 Response rate

\begin{tabular}{lllll}
\hline & $\begin{array}{l}\text { Aripiprazole } \\
(\mathbf{n}=1 \mathbf{1 9})\end{array}$ & $\begin{array}{l}\text { Blonanserin } \\
(\mathbf{n}=\mathbf{2 2})\end{array}$ & \multicolumn{2}{l}{$\begin{array}{l}\text { Group difference } \\
\left(\chi^{2} \text { test and } \boldsymbol{P} \text {-value }\right)\end{array}$} \\
\hline 4 weeks & $9(47.4 \%)$ & $10(45.5 \%)$ & $\chi^{2}=0.192$ & $P=0.661$ \\
8 weeks & $10(52.6 \%)$ & $12(54.5 \%)$ & $\chi^{2}=0.262$ & $P=0.609$ \\
12 weeks & $11(57.9 \%)$ & $14(63.6 \%)$ & $\chi^{2}=0.0133$ & $P=0.908$ \\
24 weeks & $11(57.9 \%)$ & $14(63.6 \%)$ & $\chi^{2}=0.0133$ & $P=0.908$ \\
\hline
\end{tabular}

Note: Covariate: educational history, age, PANSS scores at baseline. Abbreviation: PANSS, Positive and Negative Syndrome Scale. 
Table 4 End point change in HAMD-2I at 4, I2, and 24 weeks from the baseline

\begin{tabular}{|c|c|c|c|c|c|c|c|c|}
\hline & $\begin{array}{l}\text { Baseline } \\
\text { score }\end{array}$ & $\begin{array}{l}F_{\text {df }} \\
P \text {-value }\end{array}$ & $\begin{array}{l}\text { Change score } \\
\text { at } 4 \text { weeks }\end{array}$ & $\begin{array}{l}F_{\text {df }} \\
P \text {-value }\end{array}$ & $\begin{array}{l}\text { Change score } \\
\text { at } 12 \text { weeks }\end{array}$ & $\begin{array}{l}F_{\text {df }} \\
P \text {-value }\end{array}$ & $\begin{array}{l}\text { Change score } \\
\text { at } 24 \text { weeks }\end{array}$ & $\begin{array}{l}F_{\text {df }} \\
P \text {-value }\end{array}$ \\
\hline Aripiprazole & $22.7 \pm 8.96$ & $F_{1,42}=2.36$ & $-6.89 \pm 8.23$ & $F_{1,39}=0.078$ & $-9.16 \pm 7.38$ & $F_{1,39}=1.21$ & $-9.53 \pm 7.54$ & $F_{1,39}=3.94$ \\
\hline Blonanserin & $26.3 \pm 5.62$ & $P=0.133$ & $-9.14 \pm 6.06$ & $P=0.781$ & $-15.0 \pm 9.68$ & $P=0.279$ & $-16.5 \pm 8.25$ & $P=0.055$ \\
\hline
\end{tabular}

Note: Covariate: educational history, age, HAMD-2I scores at baseline.

Abbreviations: HAMD-2I, 2 I-item Hamilton Rating Scale for Depression; df, degrees of freedom.

that there were no significant differences for change in PANSS 5-factor "anxiety/depression" model scores between blonanserin and risperidone treatment groups, ${ }^{10}$ an 8 -week cohort study reported that blonanserin was superior to risperidone for improvement of the PANSS depression subscale score in Japanese patients with schizophrenia. ${ }^{11}$ Although the number of patients was small in this study, evidence suggests that blonanserin has both antipsychotic and antidepressive effects in patients with schizophrenia. Blonanserin has much greater affinity with serotonin $2 \mathrm{~A}$ receptor than aripiprazole. Serotonin 2A receptor antagonism might account for reduced depressive symptoms. Depressive symptoms are associated with increased risk of suicide, ${ }^{20,21}$ cognitive impairment, poor subjective well-being, and reduced subjective quality of life, ${ }^{11,12}$ and so it is vital that medication regimens target depressive symptoms as well as positive and negative symptoms.
The discontinuation rates in this study were high. We considered the following possible reasons for high discontinuation rate in this study. First, both antipsychotics do not have a sedative effect, and sedation is often required for the agitated patients. ${ }^{22}$ Second, the discontinuation rate due to other reasons such as moving and withdrawal of informed consent were relatively high. Some patients were no longer willing to continue the study owing to improved conditions.

One of the main limitations of this study is the small sample size. Several guidelines ${ }^{1-3}$ have shown that a subpopulation of first-episode patients exhibit a delayed response to antipsychotics relative to that in chronically ill patients. However, we did not perform separate subgroup analyses of PANSS and HAMD-21 scores in first-episode and multiple-episode patients because our sample size was small. We found that there were marginal differences in the

Table 5 Adverse events observed in the study (incidence $\geq 5 \%$ )

\begin{tabular}{|c|c|c|c|c|}
\hline \multirow{2}{*}{$\begin{array}{l}\text { Adverse event } \\
\text { At least one adverse event }\end{array}$} & \multirow{2}{*}{$\begin{array}{l}\text { Aripiprazole }(\mathbf{n}=\mathbf{2 2}) \\
14(63.6 \%)\end{array}$} & \multirow{2}{*}{$\begin{array}{l}\text { Blonanserin }(n=22) \\
16(72.7 \%)\end{array}$} & \multicolumn{2}{|c|}{$\begin{array}{l}\text { Group difference ( } \chi^{2} \text { test } \\
\text { and } P \text {-value) }\end{array}$} \\
\hline & & & $\chi^{2}=0.42$ & $P=0.517$ \\
\hline Somnolence & I (4.55\%) & $2(9.09 \%)$ & $\chi^{2}=0.364$ & $P=0.546$ \\
\hline Anxiety & $6(27.3 \%)$ & 9 (40.9\%) & $\chi^{2}=0.915$ & $P=0.339$ \\
\hline Insomnia & $3(13.6 \%)$ & 7 (3I.8\%) & $\chi^{2}=2.12$ & $P=0.146$ \\
\hline Dystonia & $0(0.00 \%)$ & 2 (9.09\%) & $\chi^{2}=2.87$ & $P=0.0904$ \\
\hline Rigidity & $0(0.00 \%)$ & 2 (9.09\%) & $\chi^{2}=2.87$ & $P=0.0904$ \\
\hline Akinesia & I (4.55\%) & $3(13.6 \%)$ & $\chi^{2}=1.15$ & $P=0.284$ \\
\hline Tremor & 2 (9.09\%) & $6(27.3 \%)$ & $\chi^{2}=2.54$ & $P=0.111$ \\
\hline Akathisia & 7 (31.8\%) & $5(22.7 \%)$ & $\chi^{2}=0.460$ & $P=0.498$ \\
\hline Increased salivation & $0(0.00 \%)$ & $2(9.09 \%)$ & $\chi^{2}=2.87$ & $P=0.0904$ \\
\hline Nausea/vomiting & 2 (9.09\%) & I (4.55\%) & $\chi^{2}=0.364$ & $P=0.546$ \\
\hline Constipation & 2 (9.09\%) & $3(13.6 \%)$ & $\chi^{2}=0.227$ & $P=0.634$ \\
\hline Dizziness & I (4.55\%) & 2 (9.09\%) & $\chi^{2}=0.364$ & $P=0.546$ \\
\hline Use of biperiden & I (4.55\%) & 2 (9.09\%) & $\chi^{2}=0.364$ & $P=0.546$ \\
\hline Use of lorazepam & $6(27.3 \%)$ & II (50.0\%) & $\chi^{2}=2.42 z$ & $P=0.120$ \\
\hline Use of hypnotic & 5 (22.7\%) & $3(13.6 \%)$ & $\chi^{2}=0.617$ & $P=0.432$ \\
\hline \multirow[t]{2}{*}{$\geq 7 \%$ body weight } & $2(9.09 \%)$ & $4(18.2 \%)$ & $\chi^{2}=0.785$ & $P=0.376$ \\
\hline & Aripiprazole $(n=22)$ & Blonanserin $(n=22)$ & \multicolumn{2}{|c|}{$\begin{array}{l}\text { Group difference ( } F_{\mathrm{df}} \text { and } \\
P \text {-value) }\end{array}$} \\
\hline Mean weight change $(\mathrm{kg})^{\mathrm{a}}$ & $1.47 \pm 3.23$ & $1.18 \pm 3.34$ & $F_{1,42}=-0.653$ & $P=0.424$ \\
\hline DIEPSS total scores & $1.14 \pm 2.12$ & $1.59 \pm 2.44$ & $F_{1,42}=0.434$ & $P=0.514$ \\
\hline
\end{tabular}

Note: aCovariate: body weight at baseline.

Abbreviations: DIEPSS, Drug-induced Extrapyramidal Symptoms Scale; $d f$, degrees of freedom. 
magnitude of the HAMD-21 score decrease at 24 weeks between the aripiprazole and blonanserin treatment groups $\left(F_{1,39}=3.94, P=0.055\right)$. However, it was possible that this result was a type I error due to small sample size. A second limitation is that we did not address for multiple comparisons because application of a more strict alpha level for the outcomes would have been excessively conservative in this small sample. The third limitation is that this study was not double blinded. Although raters were masked to the nature of the antipsychotic treatment and not involved in any side effect ratings or management decisions, it is possible that they were inadvertently informed of group allocation by patients. Finally, the intent-to-treat analysis using the last observation carried forward method may influence the results. ${ }^{23}$ However, if we had selected a complete analysis, our sample size would have been too small (Table S1).

\section{Conclusion}

In conclusion, our findings suggest that aripiprazole and blonanserin are both effective and well tolerated in patients with schizophrenia not receiving antipsychotics for more than 2 weeks before the treatment. Additionally, adequately well-designed double-blind randomized controlled studies are needed to further characterize the efficacy and safety comparisons between aripiprazole and blonanserin.

\section{Acknowledgments}

We thank the following colleagues who shared their data with us: Ichiro Yasue, MD, Kengo Miyahara, MD, PhD, Tatsuyo Suzuki, MD, PhD, Mari Nitta, MD, PhD, Miho Hattori, MD, PhD, Akiko Okuda, MD, PhD, Shinya Mitani, MD, PhD, Sakurako Tanaka, MD, PhD, Kayo Okada, MD, PhD, Yueren Zhao, MD, PhD, Takeo Saito, MD, PhD, Rika Tsuji, MD, Ms M Okuda-Hirabayashi, Ms M Yamamoto, Ms R Nishioka, Mr S Tsuboi, and Ms K Torii. This study was supported by Fujita Health University School of Medicine research grant and grant of the ninth research group for schizophrenia.

\section{Author contributions}

All authors contributed toward data analysis, drafting and critically revising the paper and agree to be accountable for all aspects of the work.

\section{Disclosure}

The authors declare that the research was conducted in the absence of any commercial or financial relationships that could be construed as a potential conflict of interest. Dr Kishi has received speaker's honoraria from Abbvie, Astellas, Daiichi Sankyo, Dainippon Sumitomo, Eisai, Eli
Lilly, GlaxoSmithKline, Janssen, Yoshitomi, Otsuka, Meiji, Mochida, Shionogi, Tanabe-Mitsubishi, Tsumura, Novartis, and Pfizer and has a Fujita Health University School of Medicine research grant and Grant-in-Aid for Young Scientists (B). Dr Matsuda has received speaker's honoraria from Dainippon Sumitomo, Eli Lilly, Otsuka, and Pfizer. Dr Mukai has received speaker's honoraria from Dainippon Sumitomo, Eli Lilly, and Otsuka. Dr Matsunaga has received speaker's honoraria from Eisai, Janssen, Novartis, Daiichi Sankyo, Ono, Eli Lilly, Takeda, and Otsuka and had a Fujita Health University School of Medicine research grant and Grant-in-Aid for Young Scientists (B). Dr Tabuse has received speaker's honoraria from Astellas, Dainippon Sumitomo, Eli Lilly, GlaxoSmithKline, Janssen, Yoshitomi, Otsuka, Meiji, and Pfizer. Dr Fujita has received speaker's honoraria from Eli Lilly, Mochida, GlaxoSmithKline, Janssen, Yoshitomi, and Otsuka.

Dr Iwata has received speaker's honoraria from Astellas, Dainippon Sumitomo, Eli Lilly, GlaxoSmithKline, Janssen, Yoshitomi, Otsuka, Meiji, Shionogi, Novartis, and Pfizer. The authors report no other conflicts of interest in this work.

\section{References}

1. Buchanan RW, Kreyenbuhl J, Kelly DL, et al. The 2009 schizophrenia PORT psychopharmacological treatment recommendations and summary statements. Schizophr Bull. 2010;36(1):71-93.

2. Hasan A, Falkai P, Wobrock T, et al. World Federation of Societies of Biological Psychiatry (WFSBP) Guidelines for biological treatment of Schizophrenia, part 1: update 2012 on the acute treatment of schizophrenia and the management of treatment resistance. World $J$ Biol Psychiatry. 2012;13(5):318-378.

3. NICE. Psychosis and Schizophrenia in Adults: Treatment and Management. London, UK: National Institute for Health and Care Excellence; 2014.

4. De Hert M, Vancampfort D, Correll CU, et al. Guidelines for screening and monitoring of cardiometabolic risk in schizophrenia: systematic evaluation. Br J Psychiatry. 2011;199(2):99-105.

5. Correll CU, Manu P, Olshanskiy V, Napolitano B, Kane JM, Malhotra AK. Cardiometabolic risk of second-generation antipsychotic medications during first-time use in children and adolescents. JAMA. 2009; 302(16):1765-1773.

6. Leucht S, Cipriani A, Spineli L, et al. Comparative efficacy and tolerability of 15 antipsychotic drugs in schizophrenia: a multiple-treatments meta-analysis. Lancet. 2013;382(9896):951-962.

7. Kishi T, Matsuda Y, Nakamura H, Iwata N. Blonanserin for schizophrenia: systematic review and meta-analysis of double-blind, randomized, controlled trials. J Psychiatr Res. 2013;47(2):149-154.

8. Kay SR, Fiszbein A, Opler LA. The positive and negative syndrome scale (PANSS) for schizophrenia. Schizophr Bull. 1987;13(2):261-276.

9. Kishi T, Matsuda Y, Iwata N. Cardiometabolic risks of blonanserin and perospirone in the management of schizophrenia: a systematic review and metaanalysis of randomized controlled trials. PloS One. 2014;9(2):e88049.

10. Li H, Yao C, Shi J, et al. Comparative study of the efficacy and safety between blonanserin and risperidone for the treatment of schizophrenia in Chinese patients: a double-blind, parallel-group multicenter randomized trial. J Psychiatr Res. 2015;69:102-109.

11. Hori H, Yamada K, Kamada D, et al. Effect of blonanserin on cognitive and social function in acute phase Japanese schizophrenia compared with risperidone. Neuropsychiatr Dis Treat. 2014;10:527-533. 
12. Ninomiya Y, Miyamoto S, Tenjin T, et al. Long-term efficacy and safety of blonanserin in patients with first-episode schizophrenia: a 1-year open-label trial. Psychiatry Clin Neurosci. 2014;68(12):841-849.

13. Hirose T, Kikuchi T. Aripiprazole, a novel antipsychotic agent: dopamine D2 receptor partial agonist. J Med Invest. 2005;52 Suppl:284-290.

14. Hamilton M. A rating scale for depression. J Neurol Neurosurg Psychiatry. 1960;23:56-62.

15. Jordan S, Knight J, Pointon D. Monitoring adverse drug reactions: scales, profiles, and checklists. Int Nurs Rev. 2004;51(4):208-221.

16. Inada T, Yagi G. Current topics in neuroleptic-induced extrapyramidal symptoms in Japan. Keio J Med. 1996;45(2):95-99.

17. Inada $T$, Yagi G, Miura S. Extrapyramidal symptom profiles in Japanese patients with schizophrenia treated with olanzapine or haloperidol Schizophr Res. 2002;57(2-3):227-238.

18. Leucht S, Corves C, Arbter D, Engel RR, Li C, Davis JM. Secondgeneration versus first-generation antipsychotic drugs for schizophrenia: a meta-analysis. Lancet. 2009;373(9657):31-41.
19. Khanna P, Suo T, Komossa K, et al. Aripiprazole versus other atypical antipsychotics for schizophrenia. Cochrane Database Syst Rev. 2014; 1:CD006569.

20. Fuller-Thomson E, Hollister B. Schizophrenia and suicide attempts: findings from a representative community-based Canadian sample. Schizophr Res Treatment. 2016;2016:3165243.

21. Togay B, Noyan H, Tasdelen R, Ucok A. Clinical variables associated with suicide attempts in schizophrenia before and after the first episode. Psychiatry Res. 2015;229(1-2):252-256.

22. Kishi T, Matsunaga S, Iwata N. Intramuscular olanzapine for agitated patients: a systematic review and meta-analysis of randomized controlled trials. J Psychiatr Res. 2015;68:198-209.

23. Mallinckrodt CH, Kaiser CJ, Watkin JG, Molenberghs G, Carroll RJ. The effect of correlation structure on treatment contrasts estimated from incomplete clinical trial data with likelihood-based repeated measures compared with last observation carried forward ANOVA. Clinical trials. 2004;1(6):477-489. 


\section{Supplementary materials}

Table SI Discontinuation rate

\begin{tabular}{lll}
\hline Number of patients & Aripiprazole & Blonanserin \\
\hline Randomized & 22 & 22 \\
Completed the trial (\%) & $3(13.6)$ & $7(31.8)$ \\
Discontinued the trial (\%) & $19(86.4)$ & $15(68.2)$ \\
The reasons of discontinuation & & $7(31.8)$ \\
Inefficacy (\%) & $3(13.6)$ & $4(18.2)$ \\
Adverse events (\%) & $5(22.7)$ & $4(18.2)$ \\
Other reasons (\%) & $11(50.0)$ & \\
\hline
\end{tabular}

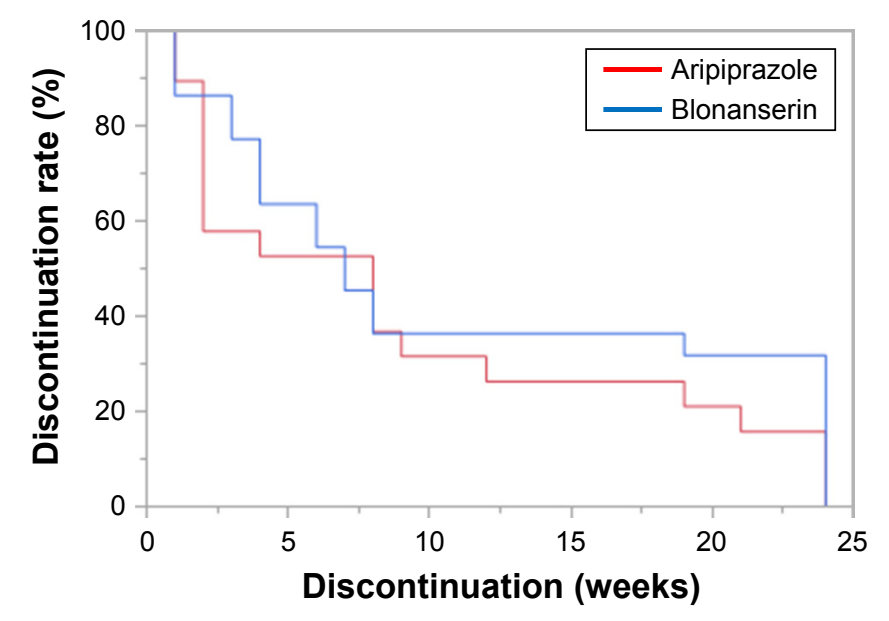

Figure SI Discontinuation rate: Kaplan-Meier analysis.

Table S2 End point change in PANSS scores at 4, 8, 12, and 24 weeks from the baseline (aripiprazole group)

\begin{tabular}{|c|c|c|c|c|c|c|c|c|}
\hline $\begin{array}{l}\text { Mean score } \\
\text { at baseline }\end{array}$ & $\begin{array}{l}\text { Mean score } \\
\text { at } 4 \text { weeks }\end{array}$ & $\begin{array}{l}t_{d f} \\
P \text {-value }\end{array}$ & $\begin{array}{l}\text { Mean score } \\
\text { at } 8 \text { weeks }\end{array}$ & $\begin{array}{l}t_{d f} \\
P \text {-value }\end{array}$ & $\begin{array}{l}\text { Mean score } \\
\text { at } 12 \text { weeks }\end{array}$ & $\begin{array}{l}t_{\mathrm{df}} \\
P \text {-value }\end{array}$ & $\begin{array}{l}\text { Mean score } \\
\text { at } 24 \text { weeks }\end{array}$ & $\begin{array}{l}t_{d f} \\
P \text {-value }\end{array}$ \\
\hline \multicolumn{9}{|c|}{ PANSS total score } \\
\hline $102.1 \pm 15.6$ & $84.1 \pm 18.3$ & $\begin{array}{l}t_{18}=-4.80 \\
P=0.0001\end{array}$ & $81.3 \pm 20.1$ & $\begin{array}{l}t_{18}=-5.47 \\
P<0.0001\end{array}$ & $81.5 \pm 19.6$ & $\begin{array}{l}t_{18}=-5.44 \\
P<0.0001\end{array}$ & $80.0 \pm 21.6$ & $\begin{array}{l}t_{18}=-5.61 \\
P<0.0001\end{array}$ \\
\hline \multicolumn{9}{|c|}{ PANSS positive subscale score } \\
\hline $25.4 \pm 5.07$ & $|9.2 \pm 5.7|$ & $\begin{array}{l}t_{18}=-4.61 \\
P=0.0002\end{array}$ & $18.4 \pm 6.08$ & $\begin{array}{l}t_{18}=-5.29 \\
P<0.0001\end{array}$ & $18.4 \pm 6.09$ & $\begin{array}{l}t_{18}=-5.40 \\
P<0.0001\end{array}$ & $18.0 \pm 6.60$ & $\begin{array}{l}t_{18}=-5.38 \\
P<0.0001\end{array}$ \\
\hline \multicolumn{9}{|c|}{ PANSS negative subscale score } \\
\hline $24.4 \pm 6.99$ & $20.6 \pm 5.31$ & $\begin{array}{l}t_{18}=-3.51 \\
P=0.0025\end{array}$ & $20.3 \pm 5.30$ & $\begin{array}{l}t_{18}=-3.80 \\
P=0.0013\end{array}$ & $20.4 \pm 5.19$ & $\begin{array}{l}t_{18}=-3.40 \\
P=0.0032\end{array}$ & $19.9 \pm 5.49$ & $\begin{array}{l}t_{18}=-3.98 \\
P=0.0009\end{array}$ \\
\hline \multicolumn{9}{|c|}{ PANSS general subscale score } \\
\hline $52.3 \pm 8.65$ & $44.3 \pm 10.2$ & $\begin{array}{l}t_{18}=-4.43 \\
P=0.0003\end{array}$ & $42.6 \pm 11.4$ & $\begin{array}{l}t_{18}=-5.11 \\
P<0.0001\end{array}$ & $42.6 \pm 11.2$ & $\begin{array}{l}t_{18}=-5.10 \\
P<0.0001\end{array}$ & $42.1 \pm 12.0$ & $\begin{array}{l}t_{18}=-5.19 \\
P<0.0001\end{array}$ \\
\hline
\end{tabular}

Abbreviations: PANSS, Positive and Negative Syndrome Scale; df, degrees of freedom. 
Table S3 End point change in PANSS scores at 4, 8, 12, and 24 weeks from the baseline (blonanserin group)

\begin{tabular}{|c|c|c|c|c|c|c|c|c|}
\hline $\begin{array}{l}\text { Mean score } \\
\text { at baseline }\end{array}$ & $\begin{array}{l}\text { Mean score } \\
\text { at } 4 \text { weeks }\end{array}$ & $\begin{array}{l}t_{d f} \\
P \text {-value }\end{array}$ & $\begin{array}{l}\text { Mean score } \\
\text { at } 8 \text { weeks }\end{array}$ & $\begin{array}{l}t_{d f} \\
P \text {-value }\end{array}$ & $\begin{array}{l}\text { Mean score } \\
\text { at I } 2 \text { weeks }\end{array}$ & $\begin{array}{l}t_{\mathrm{df}} \\
P \text {-value }\end{array}$ & $\begin{array}{l}\text { Mean score } \\
\text { at } 24 \text { weeks }\end{array}$ & $\begin{array}{l}t_{d f} \\
P \text {-value }\end{array}$ \\
\hline \multicolumn{9}{|c|}{ PANSS total score } \\
\hline II $2.5 \pm 29.1$ & $88.0 \pm 23.5$ & $\begin{array}{l}t_{21}=-4.33 \\
P=0.0003\end{array}$ & $85.9 \pm 23.4$ & $\begin{array}{l}t_{21}=-4.86 \\
P<0.0001\end{array}$ & $83.3 \pm 23.7$ & $\begin{array}{l}t_{21}=-5.21 \\
P<0.0001\end{array}$ & $81.7 \pm 25.0$ & $\begin{array}{l}t_{21}=-5.25 \\
P<0.0001\end{array}$ \\
\hline \multicolumn{9}{|c|}{ PANSS positive subscale score } \\
\hline $27.1 \pm 7.69$ & $21.1 \pm 6.93$ & $\begin{array}{l}t_{21}=-3.99 \\
P=0.0007\end{array}$ & $20.2 \pm 6.84$ & $\begin{array}{l}t_{21}=-4.49 \\
P=0.0001\end{array}$ & $19.6 \pm 7.30$ & $\begin{array}{l}t_{21}=-4.55 \\
P=0.0002\end{array}$ & $19.1 \pm 7.68$ & $\begin{array}{l}t_{21}=-4.80 \\
P<0.0001\end{array}$ \\
\hline \multicolumn{9}{|c|}{ PANSS negative subscale score } \\
\hline $27.5 \pm 8.59$ & $21.3 \pm 6.93$ & $\begin{array}{l}t_{21}=-3.99 \\
P=0.0007\end{array}$ & $21.4 \pm 6.85$ & $\begin{array}{l}t_{21}=-3.78 \\
P=0.0011\end{array}$ & $20.1 \pm 6.23$ & $\begin{array}{l}t_{21}=-4.86 \\
P<0.0001\end{array}$ & $19.7 \pm 6.30$ & $\begin{array}{l}t_{21}=-4.95 \\
P<0.0001\end{array}$ \\
\hline \multicolumn{9}{|c|}{ PANSS general subscale score } \\
\hline $57.9 \pm 15.2$ & $45.6 \pm 11.5$ & $\begin{array}{l}t_{21}=-4.00 \\
P=0.0006\end{array}$ & $44.3 \pm 11.8$ & $\begin{array}{l}t_{21}=-4.53 \\
P=0.0002\end{array}$ & $43.5 \pm 11.7$ & $\begin{array}{l}t_{21}=-4.67 \\
P=0.000 \mathrm{I}\end{array}$ & $42.9 \pm 12.5$ & $\begin{array}{l}t_{21}=-4.66 \\
P=0.0001\end{array}$ \\
\hline
\end{tabular}

Abbreviations: PANSS, Positive and Negative Syndrome Scale; df, degrees of freedom.

Table S4 End point change in HAMD-2I at 4, 12, and 24 weeks from the baseline

\begin{tabular}{|c|c|c|c|c|c|c|c|}
\hline $\begin{array}{l}\text { Treatment } \\
\text { group }\end{array}$ & $\begin{array}{l}\text { Mean score } \\
\text { at baseline }\end{array}$ & $\begin{array}{l}\text { Mean score } \\
\text { at } 4 \text { weeks }\end{array}$ & $\begin{array}{l}\boldsymbol{t}_{\mathrm{df}} \\
P \text {-value }\end{array}$ & $\begin{array}{l}\text { Mean score } \\
\text { at } 12 \text { weeks }\end{array}$ & $\begin{array}{l}t_{d f} \\
P \text {-value }\end{array}$ & $\begin{array}{l}\text { Mean score } \\
\text { at } 24 \text { weeks }\end{array}$ & $\begin{array}{l}t_{\mathrm{df}} \\
P \text {-value }\end{array}$ \\
\hline Aripiprazole & $22.7 \pm 8.96$ & $15.8 \pm 6.15$ & $\begin{array}{l}t_{18}=-3.66 \\
P=0.0018\end{array}$ & $13.6 \pm 5.86$ & $\begin{array}{l}t_{18}=-5.4 \mathrm{I} \\
P<0.0001\end{array}$ & $13.2 \pm 5.45$ & $\begin{array}{l}t_{18}=-8.99 \\
P<0.0001\end{array}$ \\
\hline Blonanserin & $26.3 \pm 5.62$ & $17.1 \pm 6.24$ & $\begin{array}{l}t_{21}=-7.07 \\
P<0.0001\end{array}$ & II. $3 \pm 6.01$ & $\begin{array}{l}t_{21}=-7.27 \\
P<0.0001\end{array}$ & $9.82 \pm 4.37$ & $\begin{array}{l}t_{21}=-14.9 \\
P<0.0001\end{array}$ \\
\hline
\end{tabular}

Abbreviations: HAMD-2I, 2 I-item Hamilton Rating Scale for Depression; df, degrees of freedom.

\section{Publish your work in this journal}

Neuropsychiatric Disease and Treatment is an international, peerreviewed journal of clinical therapeutics and pharmacology focusing on concise rapid reporting of clinical or pre-clinical studies on a range of neuropsychiatric and neurological disorders. This journal is indexed on PubMed Central, the 'PsycINFO' database and CAS, and is the official journal of The International Neuropsychiatric Association (INA). The manuscript management system is completely online and includes a very quick and fair peer-review system, which is all easy to use. Visit http://www.dovepress.com/testimonials.php to read real quotes from published authors. 